\title{
Effect of L-Cycloserine on Cellular Responses Mediated by Macrophages and $\mathrm{T}$ Cells
}

\author{
Jae Youl CHо \\ School of Bioscience and Biotechnology and Institute of Bioscience and Biotechnology, Kangwon National University; \\ Chuncheon 200-701, Korea. Received July 4, 2007; accepted July 30, 2007
}

\begin{abstract}
In this study, we examined the immunoregulatory roles of L-cycloserine (L-CS), a sphingolipid metabolism regulator with inhibitory activity of serine palmitoyltransferase (SPT), on immune responses mediated by monocytes/macrophages and $T$ cells. Mitogenic responses of splenic lymphocytes induced by LPS, PHA, and Con A were very strongly suppressed by $\mathrm{L}-\mathrm{CS}$ with $\mathrm{IC}_{50}$ values ranging from 0.5 to $1 \mu \mathrm{M}$. In contrast, this compound less strongly blocked IL-2-induced CD8 + CTLL-2 cell proliferation with an IC S0 $_{50}$ value of $540 \mu_{\mathrm{M}}$. Interestingly, L-CS enhanced the number of IL-4-producing helper $T$ cells, indicating the favored induction of Th2 condition. Although tumor necrosis factor (TNF)- $\alpha$ and nitric oxide (NO) production was not altered under $10 \%$ FCS condition, U937 cell-cell adhesion as well as the surface level of adhesion molecules (CD29 and CD98) were significantly suppressed by L-CS. In particular, reduced serum level (5\%) under L-CS treatment strongly enhanced the production of TNF- $\alpha$ and the inhibitory potency of NO production and cell adhesion. Finally, sphingolipids (Dsphingosine and DL-dihydrosphingosine) did not remarkably abrogate L-CS-mediated $T$ cell proliferation. Therefore our data suggest that de novo sphingolipid metabolism may represent an important aspect of immunomodulatory activities mediated by $T$ cells and macrophages/monocytes, depending on serum level.
\end{abstract}

Key words L-cycloserine; macrophages; T cells; Th1/Th2 differentiation; cell-cell adhesion

Macrophages and lymphocytes play an important role in innate and adaptive immunity. ${ }^{1,2)}$ When foreign pathogens are infected, phagocytic macrophages intake the pathogens and remove their pathogenic property. At the same time, these cells act as antigen presenting cells to stimulate the proliferation of $\mathrm{T}$ cells via peptide presentation on major histocompatibility complex (MHC) class II molecule. ${ }^{3)}$ The stimulation by macrophages leads CD4 $+\mathrm{T}$ cells to proliferate and differentiate into interferon (IFN)- $\gamma$-producing helper type I (Th1) or interleukin (IL)-4-producing type II (Th2) cells. ${ }^{4}$ Eventually, these helper $\mathrm{T}$ cells participate in managing various effector functions such as antibody production by $\mathrm{B}$ cells, and killing by CD8+ cytotoxic T cells. ${ }^{5)}$ Macrophages and lymphocytes produce various soluble factors including cytokines and toxic molecules to stimulate other immune cells and directly to kill infecting pathogens. ${ }^{6)}$ Between these cells, heterotypic or homotypic cell-cell adhesion mediated by activated adhesion molecules such as $\beta 1$-integrins (CD29), $\beta 2$-intgerins (CD18), and CD43 is known to enhance their immunological functions. ${ }^{7,8}$ Such immune responses mediated by these cells are known to be controlled by a series of signaling cascades composed of protein kinase (PK) C and PKA via surface receptors (e.g. pattern recognition receptor). ${ }^{9,10)}$

Sphingolipids are membrane components found in all eukaryotic cells. In addition to structural roles in membranes, their catabolism metabolites such as ceramides and sphingosines are known to be important lipid messengers mediating various cellular responses such as proliferation, differentiation, and apoptosis. ${ }^{11,12)}$ Sphingolipid biosynthesis (de novo pathway) is first initialized using L-serine and palmitoyl-CoA by serine palmitoyltransferase (SPT), a pyridoxal phosphate-dependent enzyme, to produce 3-ketodihydrosphingosine, dihydrosphingosine, dihydroceramide, ceramide, and shingomyelin. ${ }^{13,14)}$ The key role of SPT in modulating sphingolipid levels in cells was demonstrated with various inhibitors ISP-1 (myriocin/thermozymocidin). ${ }^{15)}$ Exposure of these compounds was found clearly to disturb cellular sphingolipid metabolism and consequently to regulate proliferation, differentiation, and apoptosis of various immune cells and cancer cells, although SPT-independent pharmacological actions by these inhibitors are involved. ${ }^{16,17)}$ L-Cycloserine (L-CS) is also a potent inhibitor of SPT and was demonstrated to inhibit ganglioside, cerebroside, and sulfatide biosynthesis when intraperitoneally injected, ${ }^{18,19)}$ although it is known nonspecifically to block other pyridoxal phosphatedependent enzymes. ${ }^{20}$ ) This compound has been reported to have various biological effects such as anti-HIV replication and anti-T cell mitogenic activity. ${ }^{21,22)}$

Although higher expression of SPT was observed in various immune cells including macrophages, ${ }^{23,24)}$ the exact role of the enzyme in functional activation of macrophages and $\mathrm{T}$ cells has not been thoroughly investigated as yet. In this study, therefore, we examined the blocking effects of SPT by the SPT inhibitor L-CS on immune responses mediated by $\mathrm{T}$ cells and macrophages/monocytes. To do this, we employed several in vitro proliferation, differentiation, and functional activation models including $\mathrm{T}$ helper $(\mathrm{Th})$ cell differentiation, mitogenic proliferation of T and B cells, NO and TNF- $\alpha$ production from macrophages, and U937 cell-cell adhesion mediated by activated adhesion molecules.

\section{MATERIALS AND METHODS}

Animals Specific pathogen-free 8-week-old male $\mathrm{BALB} / \mathrm{c}$ mice were purchased from B\&K Universal (Fremont, CA, U.S.A.). Ovalbumin (OVA)-specific TCR $\alpha \beta$

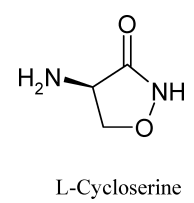

Fig. 1. Chemical Structure of L-CS 
transgenic mice (DO $11.10 \mathrm{Tg}$ ) were obtained from Jackson Laboratory (Bar Harbor, Maine). The mice were maintained in plastic cages under conventional conditions. Water and pelleted diets (Samyang, Daejeon, Korea) were supplied ad libitum. Studies were performed in accordance with guidelines of the Kangwon University Institutional Animal Care and Use Committee.

Materials L-Cycloserine, D-cycloserine, D-sphingosine, DL-erythro-dihydrosphingosine, dibutyryl cyclic AMP (dbcAMP), sulfanilamide, $N$-[1-naphthyl]-ethylenediamine dihydrochloride, $N$-monomethyl L-arginine ( $N$-MMA), 3-(4,5dimethylthiazol-2-yl)-2,5-diphenyltetrazolium bromide (MTT), Histopaque-1119, concanavalin (Con) A, phytohemagglutinin (PH) A, and lipopolysaccharide (LPS, E. coli 0111:B4) were purchased from Sigma (St. Louis, MO, U.S.A.). A771726, the bioactive metabolite of leflunomide, was supplied from Department of Chemistry in Daewoong R\&D center (Sungnam, Korea). Interleukin (IL)-2 was from Boerhinger (Mannheim, Germany). Fetal bovine serum (FBS), penicillin, streptomycin, and RPMI1640 were obtained from GIBCO (Grand Island, NY, U.S.A.). RAW264.7 cells, a murine macrophage cell line, U937 cells, a human promonocytic cell line, and CTLL-2 cells, mouse cytotoxic interleukin-2-dependent $\mathrm{T}$ cell line, were purchased from American Type Culture Collection (Rockville, MD, U.S.A.). All other chemicals were of reagent grade. The following antibodies were used in this study for aggregation assay and flow cytometric analysis. Antibodies to CD98 (ANH-18, IgG1, ascites), CD29 (MEM 101A, IgG1, ascites, kindly provided by V. Horejsi) and CD43 (161-46, ascites, IgG1, kindly provided by $\mathrm{R}$ Villela) were used as reported previously. ${ }^{8,25)}$ Recombinant human IL-2 was obtained from Takeda (Osaka, Japan), murine rIL-12 was purchased from Genetics Institute (Cambridge, MA, U.S.A.), and murine rIFN- $\gamma$ was obtained from Genentech (South San Francisco, CA, U.S.A.). Murine rIL-4 was generated from transfected P815 mastocytoma cells as high-titer culture supernatants. Monoclonal anti-mIFN- $\gamma$ (H22), monoclonal anti-IL-4 (11B11), and anti-IL-12 (Tosh) were obtained as previously described. ${ }^{26)}$

Cell Culture Splenic lymphocytes, RAW264.7, Sup-T1, Eol-1, and U937 cells were maintained in RPMI1640 supplemented with $100 \mathrm{U} / \mathrm{ml}$ of penicillin, $100 \mu \mathrm{g} / \mathrm{ml}$ of streptomycin, and $10 \%$ fetal bovine serum. In the case of CTLL-2 cell maintenance, the cells were cultured with the same medium containing $25 \mathrm{U} / \mathrm{ml}$ of IL-2. Cells were grown at $37^{\circ} \mathrm{C}$ and $5 \% \mathrm{CO}_{2}$ in humidified air.

Splenocyte Preparation Splenic lymphocytes (splenocytes) were prepared from the spleens of mice killed by cervical dislocation under sterile conditions as described previously. ${ }^{27)}$ Briefly, splenocytes were released by teasing into RPMI1640 medium supplemented with 20 mM HEPES buffer and $10 \%$ FBS. After removing red blood cells using $0.83 \%$ $\mathrm{NH}_{4} \mathrm{Cl}-$ Tris buffer $(\mathrm{pH} 7.4)$, splenocytes were washed three times in $\mathrm{Ca}^{2+}-\mathrm{Mg}^{2+}$-free Hank's balanced salt solution and resuspended to $5 \times 10^{6}$ cells $/ \mathrm{ml}$ in RPMI1640 with $100 \mathrm{U} / \mathrm{ml}$ of penicillin, $100 \mu \mathrm{g} / \mathrm{ml}$ of streptomycin, and $10 \% \mathrm{FBS}$.

Splenocyte Proliferation Assay Splenocytes $\left(5 \times 10^{6}\right.$ cells $/ \mathrm{ml}$ ) were cultured in flat-bottom 96 -well plates in the presence and absence of various $\mathrm{T}$ or $\mathrm{B}$ lymphocyte mitogens [Con A $(1 \mu \mathrm{g} / \mathrm{ml})$, PHA $(10 \mu \mathrm{g} / \mathrm{ml})$ and LPS $(10 \mu \mathrm{g} / \mathrm{ml})$ ] with L-CS in a total volume of $200 \mu \mathrm{l} /$ well at the same condi- tions for $48 \mathrm{~h}^{27)}$ The proliferation assay was performed by MTT assay.

IL-2-Dependent Cell Proliferation Assay CTLL-2 cells were harvested from IL-2-containing growth medium and washed twice with RPMI 1640. Cells were resuspended in RPMI 1640 including $10 \%$ FBS without IL-2 to $5 \times 10^{5}$ cells $/ \mathrm{ml}$. Fifty microliters of cell suspension were placed into each well of a 96-well tissue culture plate and incubated in the presence or absence of L-CS and $25 \mathrm{U} / \mathrm{ml}$ of IL-2 for 48 h. $^{27)}$

MTT Assay (Colorimetric Assay) for Measurement of Cell Proliferation Cell proliferation was measured by conventional MTT assay. At $4 \mathrm{~h}$ prior to culture termination, $10 \mu \mathrm{l}$ of MTT solution $(10 \mathrm{mg} / \mathrm{ml}$ in phosphate bufferedsaline) was continuously cultured until termination. The reaction was stopped by addition of $15 \%$ sodium dodecyl sulfate in $1.5 \mathrm{~N} \mathrm{HCl}$ into each well for solubilization of formazan and the optical density (OD) at $570 \mathrm{~nm}\left(\mathrm{OD}_{570}\right)$ was measured by a microplate Spectramax 250 microplate reader (Molecular Devices, Sunnyvale, CA, U.S.A.).

$T$ Cell Activation and Phenotype Differentiation DO11.10 splenocytes were purified on a density gradient (Histopaque-1119) and activated in the presence or absence of L-CS $(100 \mu \mathrm{M})$ by $0.3 \mu \mathrm{M}$ chicken OVA peptide $323-339$ at $3 \times 10^{6}$ cells $/ \mathrm{ml}$ in RPMI 1640 with $10 \%$ FBS. For Th1 development, $\mathrm{T}$ cells were activated in the presence of IL-12 $(10 \mathrm{U} / \mathrm{ml})$ and anti-IL-4 antibody $11 \mathrm{~B} 11(10 \mu \mathrm{g} / \mathrm{ml}){ }^{28)}$ For Th2 development, cells were activated in the presence of anti-IL-12 (TOSH) $(3 \mu \mathrm{g} / \mathrm{ml})$ and IL-4 $(100 \mathrm{U} / \mathrm{ml}) .{ }^{28)}$ For passage, $\mathrm{T}$ cells were harvested $7 \mathrm{~d}$ after the previous activation, washed, and restimulated with $0.3 \mu \mathrm{M}$ OVA at $1.25 \times 10^{5}$ cells per milliliter and irradiated BALB/c splenocytes $(2000$ rads, $2.5 \times 10^{6}$ cells $/ \mathrm{ml}$ ).

TNF- $\alpha$ Release in Vitro The modulatory effect of L-CS on TNF- $\alpha$ release was determined as previously described. ${ }^{27)}$ L-CS was solubilized with RPMI1640. Before stimulation with LPS $(1 \mu \mathrm{g} / \mathrm{ml})$ and L-CS, RAW264.7 cells $\left(2 \times 10^{6}\right.$ cells $/ \mathrm{ml}$ ) were incubated for $18 \mathrm{~h}$ in 24-well plates under the same conditions. LPS and various concentrations of L-CS were then added to the wells for $6 \mathrm{~h}$. Supernatants were collected and assayed for TNF- $\alpha$ content using mouse TNF- $\alpha$ enzyme-linked immunosorbent assay (ELISA) kit (Amersham, Little Chalfont, Buckinghamshire, U.K.).

Determination of NO Release in Vitro RAW 264.7 cells were seeded in 96-well plates at a density of $1 \times 10^{6}$ cells/ml in RPMI1640 supplemented with $100 \mathrm{U} / \mathrm{ml}$ of penicillin, $100 \mu \mathrm{g} / \mathrm{ml}$ of streptomycin, and $10 \% \mathrm{FBS}^{27)}$ After preincubation for $18 \mathrm{~h}$, various concentrations of L-CS with LPS $(1 \mu \mathrm{g} / \mathrm{ml})$ were incubated under the same conditions for $24 \mathrm{~h}$. Nitrite in culture supernatants was measured as previously described, ${ }^{27)}$ by adding $100 \mu \mathrm{l}$ of Griess reagent $(1 \%$ sulfanilamide and $0.1 \% N$-[1-naphthyl]-ethylenediamine in $5 \%$ phosphoric acid) to $100-\mu \mathrm{l}$ samples of medium at room temperature for $10 \mathrm{~min}$. The $\mathrm{OD}$ at $550 \mathrm{~nm}\left(\mathrm{OD}_{550}\right)$ was measured by a Spectramax 250 microplate reader. The nitrite concentration $(\mu \mathrm{M})$ was calculated from sodium nitrite standard curve. The detection limit of the assay was $0.5 \mu \mathrm{M}$.

Quantitative Homotypic Cell-Cell Adhesion Assay A quantitative homotypic cell-cell adhesion assay was performed as reported previously. ${ }^{29)}$ Briefly, U937 cells were pre-incubated with L-CS at $37^{\circ} \mathrm{C}$ for $1 \mathrm{~h}$ and incubated fur- 
ther with aggregative antibodies $(1 \mu \mathrm{g} / \mathrm{ml})$ for $4-6 \mathrm{~h}$ in round-bottomed microwell plates. The numbers of non-aggregated and total cells were counted in a hemocytometer and the percentage of cells in aggregates was determined as $100 \times($ total cells-non-aggregated cells)/total cells and referred to as the control (as a percentage) calculated from the only aggregative antibody treatment group.

Flow Cytometric Analysis Expression of U937 surface adhesion molecules was determined by flow cytometric analysis as reported previously. ${ }^{29)}$ Stained cells were analyzed by FACScan (Beckton-Dickinson, San Jose, CA, U.S.A.).

Cytotoxicity Assay Cytotoxicity of L-CS was evaluated by MTT assay with a minor modification as reported previously. ${ }^{27)}$ The cell suspension of $0.5 \times 10^{6}$ cells $/ \mathrm{ml}$ was plated in 96-well plates. After 2-h culture, various concentrations of $\mathrm{L}-\mathrm{CS}$ were added to each well and cultured for $48 \mathrm{~h}$. Cell viability was measured by the MTT method.

Extraction of Total RNA and Semiquantitative RTPCR Amplification The total RNA from the LPS-treated RAW264.7 cells was prepared by adding TRIzol Reagent (Gibco BRL) according to the manufacturer's protocol. Semiquantitative RT reactions were conducted using MuLV reverse transcriptase as reported previously ${ }^{30}$ The primers (Bioneer, Daejeon, Korea) were used as previously reported. $^{31)}$

Statistical Analysis All values, expressed as the mean \pm S.E.M., were obtained from four separate observations performed in triplicate or triplicate measurements $(n=3)$. Data were analyzed by a one-way analysis of variance followed by post hoc Dunnett's test to determine the statistical significance of the differences. $p<0.05$ was considered statistically significant.
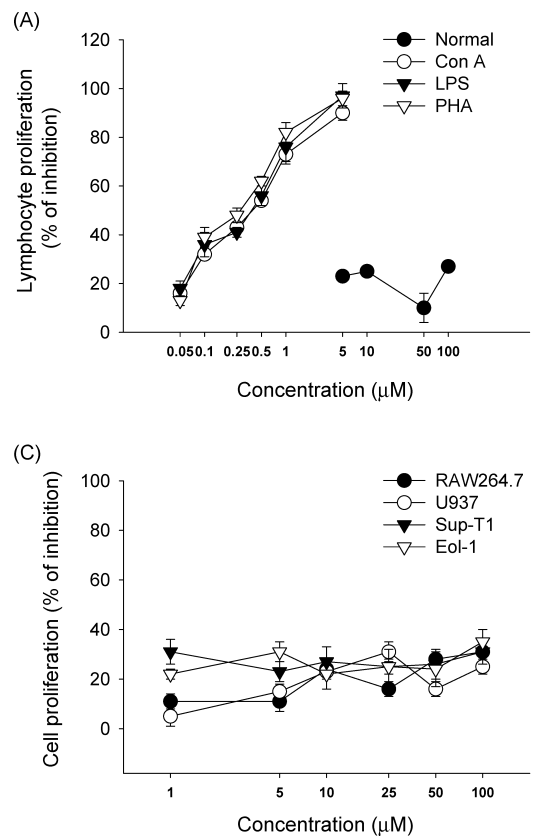

\section{RESULTS}

Effect of L-CS on T Cell Proliferation Since L-CS has been reported to suppress human peripheral blood-derived $\mathrm{T}$ lymphocyte proliferation, ${ }^{22}$ ) we first evaluated in detail whether L-CS is also able to suppress the proliferation of splenic lymphocytes prepared from mouse spleen. Figure 2A shows that L-CS was a potent inhibitor of splenocyte proliferation. Thus it blocked both T (Con A and PHA) and B (LPS) cell mitogen-mediated splenocyte proliferation $\left(\mathrm{IC}_{50}\right.$ values of $0.56,0.62$, and $0.68 \mu \mathrm{M}$ ), without blocking the viablity of normal splenocytes. In contrast, D-CS did not block either Con A-mediated proliferation of splenocytes or viability of normal splenocytes (Fig. 2B), indicating that L-CS-mediated inhibition is stereochemical dependent. To confirm whether L-CS simply blocks cell proliferation itself, several cancer cell lines were chosen and the inhibitory effect by the compound was evaluated. As Fig. $2 \mathrm{C}$ shows, there was no dosedependent inhibition of the cells by L-CS up to $100 \mu \mathrm{M}$.

Concomitantly, whether L-CS is capable of down-regulating CD8 $+\mathrm{T}$ cell proliferation was also tested using CTLL-2 cells, an IL-2-dependent CD8 + cell line. The standard curve by IL-2 showed linearity $\left(r^{2}=0.940\right)$ between 0.3 and $40 \mathrm{U} / \mathrm{ml}$ as a final concentration (data not shown). As Fig. 2D depicts, L-CS dose-dependently suppressed CTLL-2 cell proliferation with an $\mathrm{IC}_{50}$ value of $46 \mu \mathrm{M}$, while D-CS did not, suggesting that the inhibitory potency toward CTLL-2 cells was relatively lower than that of splenocytes with stereochemical specificity. Positive control drugs A771726 (a leflunomide metabolite) and dbcAMP dose-dependently inhibited proliferation with $\mathrm{IC}_{50}$ values of 11.2 and $576 \mu \mathrm{M}$, respectively.

Effect of L-CS on Helper T (Th) Cell Differentiation Since L-CS strongly diminished CD4 $+\mathrm{T}$ cell proliferation,
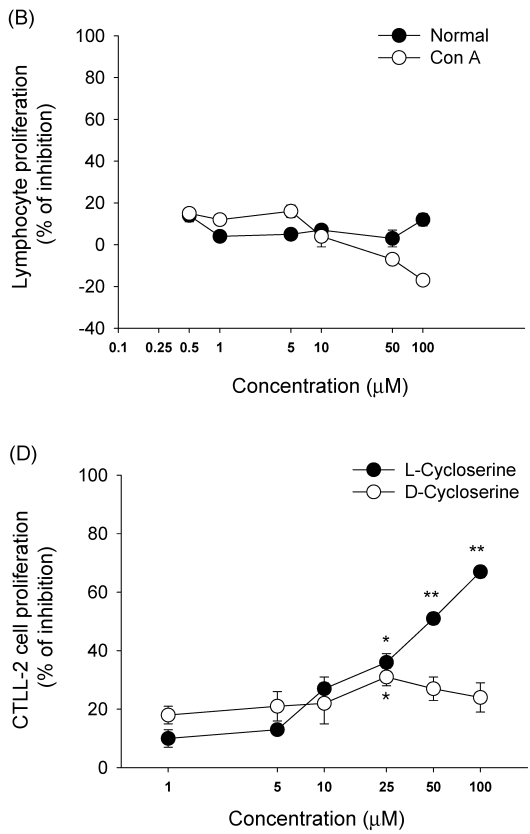

Fig. 2. Effect of L-CS on Splenic Lymphocyte and CD8+ CTLL-2 Cell Proliferation

(A, B) Splenocytes $\left(5 \times 10^{6} \mathrm{cells} / \mathrm{ml}\right)$ were incubated with various concentrations of L-CS or D-CS in the presence or absence of mitogens such as Con A $(1 \mu \mathrm{g} / \mathrm{ml})$, LPS $(10 \mu \mathrm{g} / \mathrm{ml})$, and PHA $(10 \mu \mathrm{g} / \mathrm{ml})$ for $48 \mathrm{~h}$. (C) Cells $\left(5 \times 10^{5}\right.$ cells $\left./ \mathrm{ml}\right)$ were treated with various concentrations of L-CS for $48 \mathrm{~h}$. (D) CTLL- 2 cells $\left(5 \times 10^{5}\right.$ cells/ml) were treated with various concentrations of L-CS or D-CS in the presence or absence of IL-2 (50 U/ml). Cell proliferation was evaluated by conventional MTT assay as described in Materials and Methods. $* p<0.05$ and $* * p<0.01$ represent significant difference compared with control (IL-2-treated group) (D). 


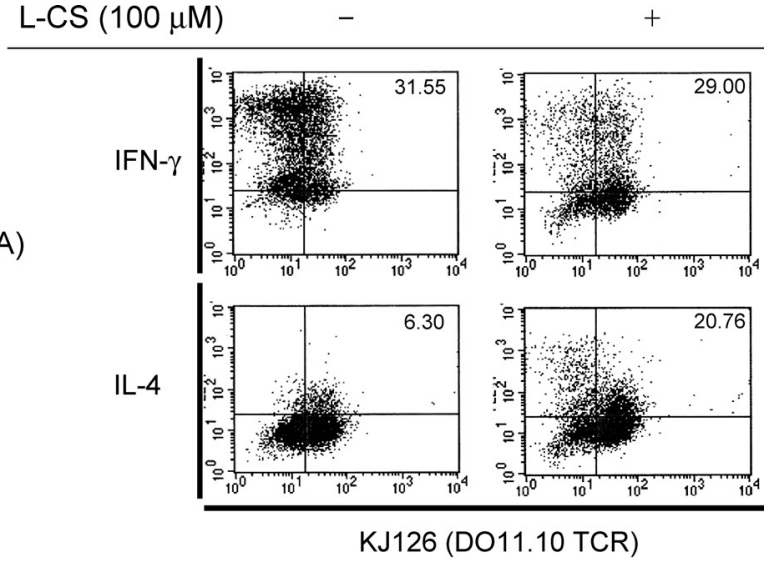

L-CS $(100 \mu \mathrm{M})$

(B)
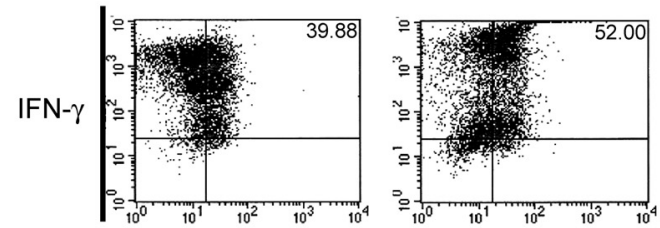

IL-4
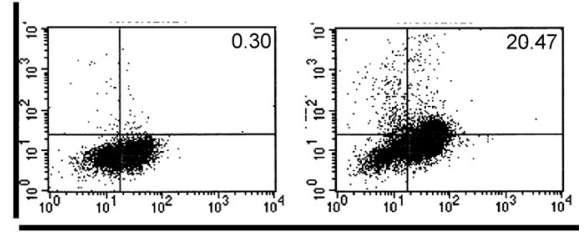

KJ126 (DO11.10 TCR)

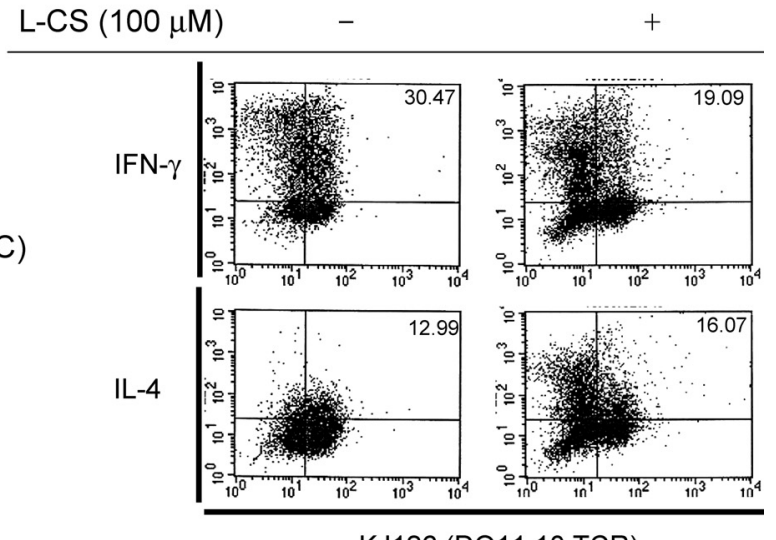

KJ126 (DO11.10 TCR)

Fig. 3. Effect of L-CS on Th1/Th2 Differentiation

Splenocytes $\left(5 \times 10^{6}\right.$ cells $\left./ \mathrm{ml}\right)$ were incubated with L-CS $(100 \mu \mathrm{M})$ under (A) drift [without any cytokine or antibody], (B) Th1 [IL-12 and anti-IL-4 (11B11)], or (C) Th2 [IL-4, anti-IL-12 (TOSH)] conditions. The cells were allowed to proliferate and expand for $7 \mathrm{~d}$ and were harvested, restimulated, and analyzed for IFN- $\gamma$ or IL-4 production by intracellular staining as described in Materials and Methods. Numbers in the upper right are the percentage of live gated cells in this quadrant. Similar results were obtained in two experiments.

we next examined whether this compound was capable of modulating Th cell differentiation. To do this experiment, the DO11.10 transgenic mouse model using OVA peptide was employed. ${ }^{28)}$ As Fig. 3 indicates, ovalbumin treatment (drift condition) in the absence of IL-12 and IL-4 mostly induced Th1 polarity (Fig. 3A). However, Th1 polarity with exogenous IL-12 increased in IFN- $\gamma$-producing $\mathrm{T}$ cells and decreased in IL-4-producing T cells (Fig. 3B). In contrast, Th2 polarity (IL-4 co-treatment) enhanced IL-4-producing $\mathrm{T}$

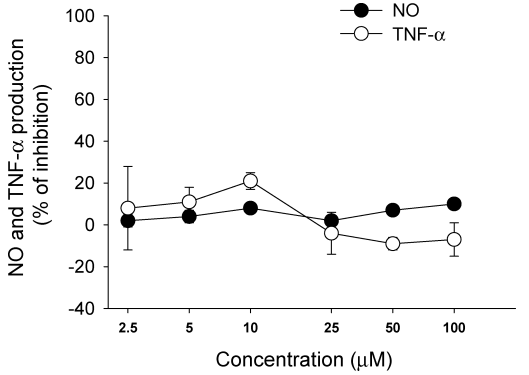

Fig. 4. Effect of L-CS on Production of TNF- $\alpha$ and NO in LPS-Activated RAW264.7 Cells

RAW264.7 cells $\left(1 \times 10^{6}\right.$ cells $\left./ \mathrm{ml}\right)$ were incubated with various concentrations of $\mathrm{L}$ $\mathrm{CS}$ in the presence or absence of LPS $(1 \mu \mathrm{g} / \mathrm{ml})$ for $6 \mathrm{~h}(\mathrm{TNF}-\alpha)$ or $24 \mathrm{~h}(\mathrm{NO})$. Culture supernatants were assayed for TNF- $\alpha$ and NO determination by ELISA or Griess assay.

cells, although IFN- $\gamma$-producing cells were not altered compared with the drift condition (Fig. 3C)

Interestingly, L-CS exposure to splenic lymphocytes under these conditions remarkably up-regulated IL-4-producing T cells, indicating that $\mathrm{L}-\mathrm{CS}$ may stimulate $\mathrm{T}$ cell differentiation into Th2 polarity.

Effect of L-CS on Macrophage Function To compare the inhibitory effect of L-CS in T cells, the regulatory role of this compound on macrophage functions involved in inflammatory responses was also evaluated. Macrophage-like RAW264.7 cells stimulated with LPS $(1 \mu \mathrm{g} / \mathrm{ml})$ produced higher amounts of NO (30 to $40 \mu \mathrm{M})$ and TNF- $\alpha$ (10 to $12 \mathrm{ng} / \mathrm{ml}$ ) from basal levels (NO: 0.5 to $1 \mu \mathrm{M}$ and TNF- $\alpha$ : 0.01 to $0.03 \mathrm{ng} / \mathrm{ml}$ ) under $10 \%$ FBS conditions. L-CS, however, did not significantly affect the production of these inflammatory mediators (Fig. 4), indicating that L-CS may not modulate inflammatory responses by macrophage under $10 \%$ FBS conditions. N-MMA also inhibited NO release from LPS-stimulated RAW264.7 cells with an $\mathrm{IC}_{50}$ value of $179.7 \mu \mathrm{M}$ (data not shown).

Effect of L-CS on the Functional Activation and Expression of Adhesion Molecules Since adhesion molecules play an important role in cell-cell interaction between activated macrophages [(as well as dendritic cells) acting as antigen-presenting cells] and T cells or endothelial cells, ${ }^{7,10)}$ we next examined the effect of L-CS on the expression of major adhesion molecules of macrophages using flow cytometry and their functional activation using homotypic cell-cell adhesion assays under 10\% FBS conditions. Interestingly, LCS significantly reduced surface levels of adhesion molecules such as CD29 and CD98 but not CD43 up to 20 to $35 \%$ (Fig. 5A). Moreover, L-CS also blocked functional activation of CD98, CD29, and CD43 (induced by function-activating antibody to CD29) assessed by homotypic aggregation of U937 cells, in a dose-dependent manner up to $500 \mu \mathrm{M}$ (Fig. 5B). In particular, since we found that PKA and PKC can negatively modulate CD98-mediated cell-cell adhesion, ${ }^{25}$ the effect of L-CS on CD98-mediated adhesion events under co-treatment with PKA and PKC inhibitors was also examined. As shown in Fig. 5C, L-CS still blocked enhanced adhesion events and interestingly the inhibitory potency was increased when L-CS was co-treated with the PKA inhibitor KT5720, suggesting that blocking PKA may enhance L-CS mediated inhibition in CD98-mediated cell-cell adhesion. A control drug, U0126 (25 $\mu \mathrm{M})$, almost completely blocked 
(A)
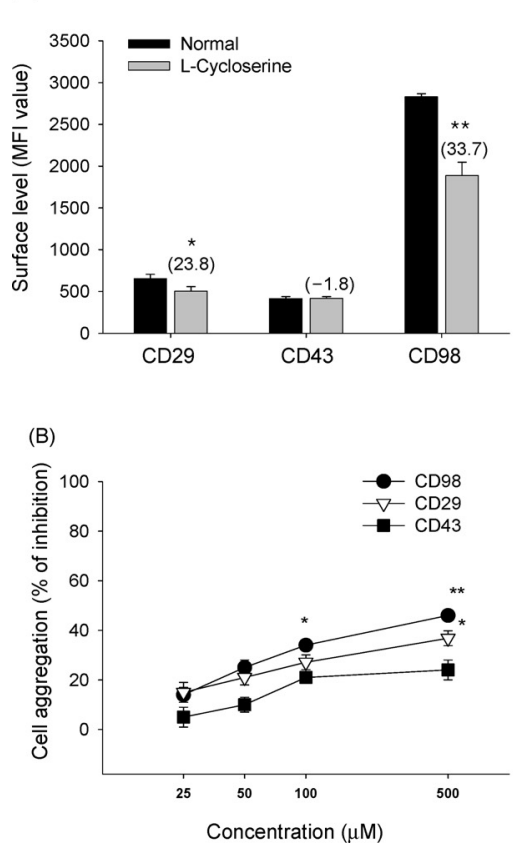

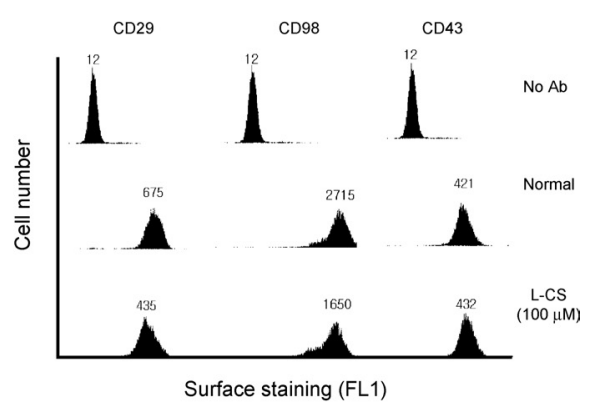

(C)

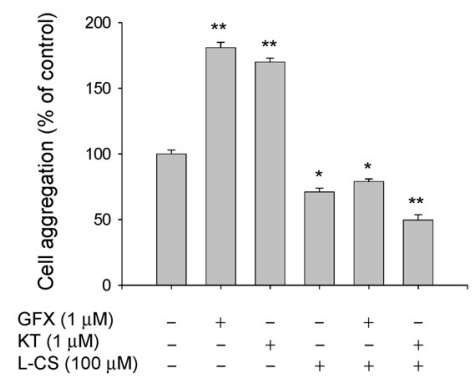

Fig. 5. Effect of L-CS on Surface Expression of Adhesion Molecules and Their Activation

(A) The surface levels of adhesion molecules (CD98, CD43, CD147) were determined by flow cytometric analysis as described in Materials and Methods. Left panel: MFI values; Right panel: histogram. Similar results were obtained in two experiments. Numbers indicate (\% of inhibition) (left panel) or MFI value of each peak (right panel). (B, C) U937 cells were incubated with the indicated concentrations of L-CS and kinase inhibitors [GFX (GF109203X, a PKC inhibitor) and KT (KT5720, a PKA inhibitor)] in the presence or absence of pro-aggregative (agonistic) antibodies [antibodies ( $1 \mu \mathrm{g} / \mathrm{ml}$ each) to CD98 (ANH-18), CD29 (MEM 101A), and CD43 (161-46)] for 4h. The extent of cell-cell adhesion was determined by quantitative homotypic cell-cell adhesion assay as described in Materials and Methods. $* p<0.05$ and $* * p<0.01$ represent significant difference compared with normal (A) or control (agonistic antibody alone) (B, C).

CD29-induced cell-cell aggregation up to $90 \%$ (data not shown).

Effect of Serum Level and Sphingolipids in L-CS-Mediated Modulation of Cellular Events Based on observations that FBS modulates sphingolipid metabolism, ${ }^{32-34)}$ we next investigated whether FBS affects the modulatory effects of L-CS. First, the serum effect on cell proliferation was evaluated using L-CS-treated cancer cell lines. As shown in Fig. 6A, L-CS exposure to U937, RAW264.7, and Sup-T1 cells under $10 \%$ FBS conditions inhibited cell proliferation up to $20 \%$ to $30 \%$. Five percent FBS conditions slightly down-regulated the inhibitory potency of L-CS. In contrast, $25 \mu \mathrm{M} \mathrm{C}_{2}-$ ceramide (Cer) markedly up-regulated the blocking effect of L-CS 8-fold in U937 cells and similarly in other cell lines (Fig. 6A), suggesting that the regulatory effect by L-CS may be different from that by ceramide. Unlike the proliferation assays, inflammatory responses by LPS-activated macrophages such as NO and TNF- $\alpha$ production were strikingly altered by serum content (Figs. 6B, C). Thus 5\% FBS significantly increased the production of TNF- $\alpha$ and NO inhibition in L-CS/LPS-treated RAW264.7 cells compared with $10 \%$ condition. Similarly, RT-PCR analysis of TNF- $\alpha$ mRNA also confirmed the enhanced effect of $5 \%$ FCS in L-CS/LPStreated cells (Fig. 6D). However, the secreted levels of NO and TNF- $\alpha$ were not strikingly different between $5 \%$ and $10 \%$. Furthermore, 5\% serum enhanced L-CS inhibition of CD98-mediated cell-cell adhesion more than 10\% (Table 1), suggesting that the modulatory activity of L-CS may be serum dependent. Finally, we attempted to confirm whether sphingolipids (D-sphingosine and DL-dihydrosphingosine), known to abrogate ISP-1 effect on CTLL-2 cells, were able to interrupt $\mathrm{L}-\mathrm{CS}$-mediated inhibition of $\mathrm{T}$ cell proliferation under PHA treatment. ${ }^{35)}$ As Fig. 6E shows, co-treatment of sphingolipids did not drastically abrogate L-CS inhibition. Thus $1-5 \mu \mathrm{M}$ of sphingosine only slightly attenuated L-CS effect, and dihydrosphingosine treatment dose-dependently boosted L-CS-mediated inhibitim of T cell proliferation. Unfortunately, we could not treat these sphingolipids up to $1 \mathrm{mM}$, an effective concentration for abolishment of ISP-1 effect, ${ }^{35)}$ due to their cytotoxicity.

\section{DISCUSSION}

Previously, L-CS has been shown to be a potent inhibitor of sphingolipid biosynthesis altering membrane sphingolipid composition, ${ }^{19,22)}$ although some papers pointed out its inhibitory effect on pyridoxal phosphate-dependent enzymes. ${ }^{20)}$ As a result, it has been reported that the compound potently down-regulated $\mathrm{T}$ cell proliferation via decreased levels of CD4. ${ }^{21)}$ Furthermore, other SPT inhibitors such as ISP- $1^{17)}$ were shown to block allogenic responses of $\mathrm{CD} 4+$ and $\mathrm{CD} 8+\mathrm{T}$ cells and consequently suppress graft rejection of organs. ${ }^{36,37)}$ Based on these reports, we examined whether LCS was able to modulate the proliferation of splenic lymphocytes induced by LPS, Con A, and PHA and their differentiation into Th1 or Th2 cells. Interestingly, our data indicate that L-CS modulates mitogenic responses of the lymphocytes, since it also blocked LPS-induced B cell blastogenesis without interfering with normal splenocyte viability (Fig. 2A). In particular, it is interesting to note that L-CS seems preferentially to induce Th2 differentiation under several Th cell differentiation conditions (Fig. 3), although the exact mechanisms have not yet been elucidated. The effect of L-CS on IL2-dependent CTLL-2 cell proliferation and normal cancer 


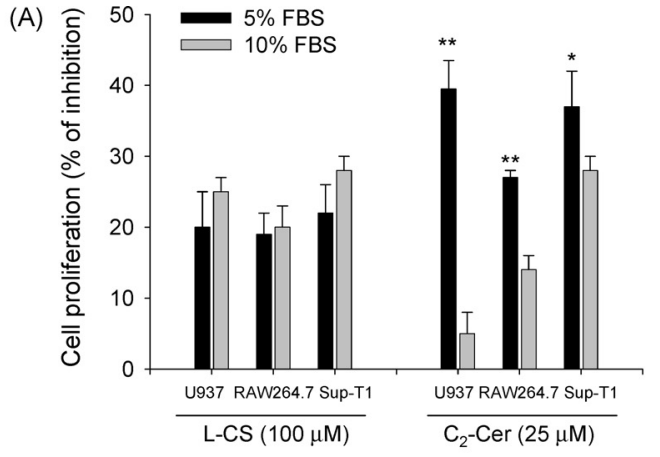

(C)

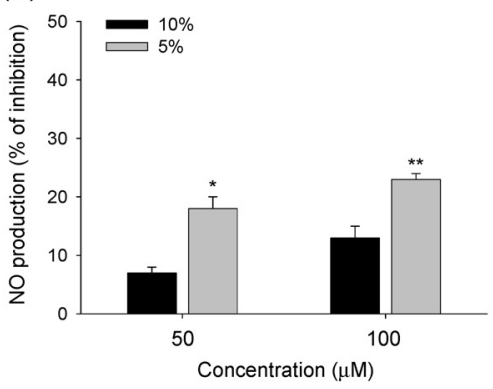

(B)

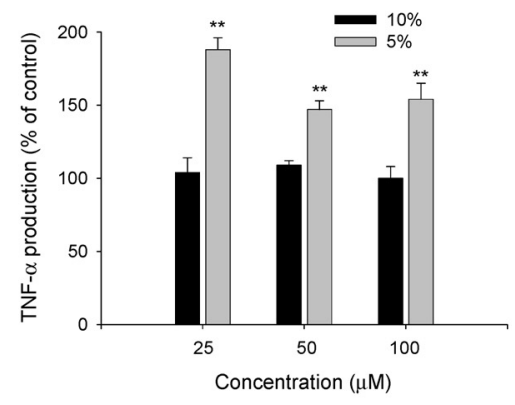

(D)

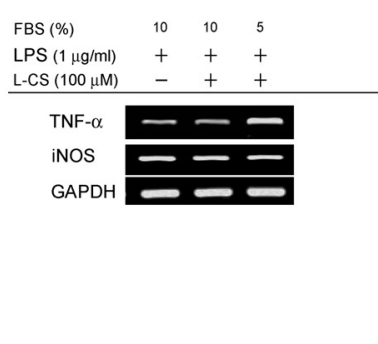

(E)

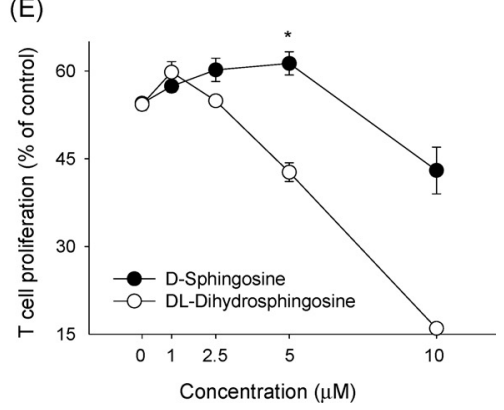

Fig. 6. Effect of Serum Level and Sphingolipids on L-CS-Mediated Regulation of Cell Proliferation and TNF- $\alpha$ and NO Production

(A) Cells $\left(5 \times 10^{5}\right.$ cells $\left./ \mathrm{ml}\right)$ were treated with L-CS or $\mathrm{C}_{2}$-ceramide under $5 \%$ or $10 \%$ for $48 \mathrm{~h}$ FCS. The extent of cell proliferation was evaluated by conventional MTT assay as described in Materials and Methods. (B, C) RAW264.7 cells $\left(1 \times 10^{6}\right.$ cells $\left./ \mathrm{ml}\right)$ cultured in $5 \%$ or $10 \%$ FCS conditions were incubated with various concentrations of L-CS in the presence or absence of LPS $(1 \mu \mathrm{g} / \mathrm{ml})$ for $6 \mathrm{~h}$ (TNF- $\alpha$ ) or $24 \mathrm{~h}$ (NO). Culture supernatants were assayed for TNF- $\alpha$ and NO determination by ELISA or Griess assay. (D) RAW264.7 cells $\left(5 \times 10^{6}\right.$ cells $\left./ \mathrm{ml}\right)$ cultured in $5 \%$ or $10 \%$ FCS conditions were incubated with L-CS (100 $\left.\mu \mathrm{M}\right)$ in the presence or absence of LPS (1 $\left.\mu \mathrm{g} / \mathrm{ml}\right)$ for $6 \mathrm{~h}$. After preparing total RNA and cDNA, mRNA levels of TNF- $\alpha$, iNOS, and GAPDH were determined by RT-PCR as described in Materials and Methods. (E) Splenocytes ( $5 \times 10^{6}$ cells/ml) were incubated with L-CS $(0.5 \mu \mathrm{M})$ and D-sphingosine or DL-dihydrosphingosine in the presence or absence of PHA $(10 \mu \mathrm{g} / \mathrm{ml})$ for $48 \mathrm{~h}$. $* p<0.05$ and $* * p<0.01$ represent significant difference compared with $10 \%$ FCS conditions $(\mathrm{A}, \mathrm{B}, \mathrm{C})$ or L-CS alone (E).

Table 1. Effect of FCS on L-Cycloserine-Mediated Regulation of Cell-Cell Aggregation

\begin{tabular}{|c|c|c|c|c|c|c|}
\hline \multirow{3}{*}{$\begin{array}{c}\text { Aggregation } \\
\text { signals } \\
\text { L-CS }\end{array}$} & \multicolumn{6}{|c|}{ Cell aggregation (\% of aggregation) } \\
\hline & \multicolumn{2}{|c|}{ CD98 } & \multicolumn{2}{|c|}{$\mathrm{CD} 29$} & \multicolumn{2}{|c|}{$\mathrm{CD} 43$} \\
\hline & - & + & - & + & - & + \\
\hline $5 \% \mathrm{FCS}$ & $59 \pm 5.1$ & $37.4 \pm 4.2$ & $47.6 \pm 3.6$ & $38.5 \pm 2.1$ & $90.9 \pm 2.4$ & $78.3 \pm 5.5$ \\
\hline $10 \% \mathrm{FCS}$ & $66.5 \pm 0.9$ & $52.9 \pm 3.3$ & $62.7 \pm 1.6$ & $56.2 \pm 2.2$ & $82.9 \pm 7.8$ & $76.2 \pm 2.6$ \\
\hline
\end{tabular}

cell propagation (Figs. 2C, D) suggests that the mitogenic responses of splenic lymphocytes are probably the most sensitive immunopharmacological target of L-CS. Indeed, the inhibitory potency $\left(\mathrm{IC}_{50}=0.56 \mu \mathrm{M}\right)$ against mitogenic responses was higher than that of other immunosuppressants such as leflunomide and methotraxate with $\mathrm{IC}_{50}$ values from 5 to $100 \mu \mathrm{M}^{27}{ }^{27}$ The strong inhibitory potency seems to be in part related to diminish cytokines involved in $\mathrm{T}$ cell proliferation (such as IL-2), according to a previous report, ${ }^{22)}$ although the suppressive effect was not drastic.

Since the blockade of sphingolipid metabolism by L-CS altered membrane composition and consequently diminished surface levels of CD4 in T cells, ${ }^{21,22)}$ a possibility that L-CS is able to modulate receptor-mediated immune responses by monocytes/macrophages, such as pro-inflammatory molecule production and cell-cell interaction, was assumed. Indeed, it has been shown that various receptors (e.g. TLRs and scavenger receptors) in monocytes/macrophages are acting as a counter-receptor to microbial products such as membrane components. $^{38)}$ To address this, macrophage-like RAW264.7 cells and monocytic U937 cells were chosen and stimuli (LPS or agonistic antibodies) to activate the surface receptors TLR4 and adhesion molecules were employed to evaluate LCS's regulatory roles. While there was no modulation by LCS on LPS-induced production of NO and TNF- $\alpha$ (Fig. 4), interestingly, U937 cell-cell adhesion was significantly blocked (Fig. 5B). Thus L-CS more strongly diminished CD98-induced cell-cell adhesion than CD43-mediated adhesion. In particular, since L-CS also suppressed surface levels of CD98 and CD29 up to 20 to $30 \%$ (Fig. 5A left panel), according to flow cytometic assay, the decreased level of CD98 and CD29 might be involved in L-CS-mediated inhibition of CD29- or CD98-mediated cell-cell adhesion. In contrast, inhibition of CD43-induced cell adhesion might be distinct from CD29- or CD98-mediated cell adhesion, since the CD43 level was not altered (Fig. 5B). Considering that L-CS effect was enhanced by PKA inhibitor KT5720 (Fig. 5C), it is preferentially possible that L-CS-induced pharmacological interruption may be effective under PKA blockade during altered membrane lipid composition. 
Several sphingolipids such as ceramide, lactosylceramide, and sphingosine-1-phosphate are known to be biologically active lipid messengers. ${ }^{39-41)}$ Initially, they were regarded as important regulators in mediating cellular apoptotic pathways. ${ }^{42)}$ Now, since they are known to be involved in various cellular signaling pathways such as inflammatory signaling, ${ }^{39,43)}$ these messengers are considered functionally multipotent biomolecules. The biosynthetic pathways for up-regulating these molecules are divided into two ways, the salvage pathway linked to sphingomyelin and the de novo pathway managed by SPT. ${ }^{44)}$ Various components are known to affect these pathways. For example, serum deprivation enhances cancer cell apoptosis in a ceramide-dependent manner and alters de novo sphingolipid biosynthesis resulting in downregulation of 3-ketosphinganine, sphinganine, sphingosine-1phosphate, and ceramide. ${ }^{33,45)}$ Therefore we also characterized SPT-mediated changes of various cellular responses under different serum levels. Interestingly, L-CS-mediated regulation of cell proliferation was not altered by serum concentrations, whereas $\mathrm{C}_{2}$-ceramide treatment imposed dramatic differences (Fig. 6A). Ceramide is necessary for cell signaling leading to cell proliferation and differentiation, ${ }^{46}$ and thus blocking ceramide synthesis by L-CS may might block cell proliferation. However, we could not obtain remarkable anti-proliferative effect under L-CS treatment, regardless of serum levels (Figs. 2C, 6A), suggesting that LCS-mediated cell proliferation regulation may not be mediated by down-regulated condition of ceramide. Furthermore, ceramide exhibited distinct regulation of cell proliferation relevant to serum levels. Considering our data and a report that SPT inhibition decreases intracellular ceramide levels by blocking de novo synthetic pathway, ${ }^{47)}$ it seems that the L-CS effect may not be totally mediated by ceramide.

In the case of functional activation of monocytes/macrophages, TNF- $\alpha$ and NO production and cell-cell adhesion seem to have more sensitive responses to sphingolipid metabolism. Thus decrease of serum percentages in culture media led monocytes and macrophages to up-regulate both TNF- $\alpha$ and NO production and to enhance the inhibitory effect of cell-cell adhesion by L-CS (Figs. 6B, C, D). Although we cannot exactly understand how disruption of sphingolipid metabolism affects TNF- $\alpha$ and NO production in a serumdependent manner, these results indicate that sphingolipid metabolism may be linked to immune responses depending on the level of serum components involved in modulating cellular responses. ${ }^{48)}$ Indeed, it has been shown that several sphingolipid metabolites including ceramide, $\alpha$-galactosylceramide, and sphingomyelin boost NO and TNF- $\alpha$ production in a Src kinase- or reactive oxygen species-dependent manner, ${ }^{49-51)}$ while sphingosine blocks LPS-induced TNF- $\alpha$ production in macrophages, even though there are several controversial reports. ${ }^{52)}$ Moreover, LPS-stimulated cytokines such as TNF- $\alpha$, IFN- $\gamma$, and IL- $1 \beta$ are known to produce intracellular ceramide. ${ }^{53,54)}$ Considering these reports, therefore, the up-regulation of activating or inhibitory effects by LCS under 5\% FBS concentrations may be mediated by some sphingolipid metabolites, which are unidentified as yet. Whether the biologically active metabolites that contribute to altering macrophage function are derived from sphingolipid metabolism in L-CS-treated cells under 5\% serum or whether a simply reduced supply of the metabolites due to lowered serum level affects NO and TNF- $\alpha$ production in LPS-activated macrophages should be identified in the future.

L-CS is also known non-specifically to inhibit other pyridoxal phosphate-dependent enzymes such as ornithine decarboxylase, histidine decarboxylase, and glutamic decarboxylase. $^{20)}$ To evaluate whether the inhibitory effect of L-CS on T cell expansion was SPT dependent, several sphingolipid metabolites such as D-sphingosine and DL-dihydroshingosine, based on a previous paper in which these metabolites strongly abrogated SPT inhibitor-mediated inhibition of CTLL-2 cell proliferation ${ }^{35)}$ were used. As Fig. 6E shows, there was no blockade of L-CS inhibition of PHA-induced T cell proliferation by the sphingolipid metabolites, suggesting that L-CS effect may be mediated not by SPT inhibition but by another pyridoxal phosphate-dependent enzyme. However, several points also suggest that another pyridoxal phosphate-dependent enzyme may not be the target of L-CS. Thus those enzymes can equally interact with racemate form of cycloserine ${ }^{20)}$ while D-cycloserine displayed weak inhibitory effect on CTLL-2 cell proliferation (Fig. 2D). Some pyridoxal phosphate-dependent enzymes (e.g. ornithine decarboxylase) are known to be highly expressed in various cancer cell lines and inhibition of the enzymes consequently reduced cancer cell proliferation. ${ }^{55)}$ Due to this, such enzyme is at present regarded as a target of anti-cancer drugs. ${ }^{55)}$ In contrast, L-CS did not strongly block the proliferation of cancer cell lines even at $100 \mu \mathrm{M}$ (Fig. 2C). Furthermore, it has been reported that pyrodixal phosphate itself can act as an antiproliferative drug against endothelial cell proliferation in a dose-dependent manner. ${ }^{56,57)}$ Hence previous reports and our data suggest that another pyridoxal phosphate-dependent enzyme may not be concluded as a real target of L-CS-mediated inhibition of $\mathrm{T}$ cell proliferation. Rather, it may be regarded that either there are several isoforms of SPT in different types of cells, ${ }^{58)}$ having distinct sensitivity to L-CS (or even ISP-1) in splenic lymphocytes and CTLL-2 cells, or another novel target of L-CS may be involved in its pharmacology. To explore these possibilities, relevant experiments will be further added.

In conclusion, we have shown that mitogenic responses of splenic lymphocytes induced by LPS, PHA, and Con A ( $\mathrm{IC}_{50}$ values ranging from 0.5 to $1 \mu \mathrm{M}$ ) were a more sensitive cellular phenomenon regulated by sphingolipid metabolism compared with $\mathrm{CD} 8+\mathrm{CTLL}-2$ cell proliferation $\left(\mathrm{IC}_{50}\right.$ value $=540 \mu \mathrm{M}$ ). In particular, L-CS also modulated $\mathrm{T}$ cell differentiation favoring the Th2 condition. Although the production of TNF- $\alpha$ and NO was not altered under $10 \%$ FBS conditions, U937 cell-cell adhesion was significantly suppressed by L-CS with a suppressed level of surface adhesion molecules (CD29 and CD98). Interestingly, reduced serum level $(5 \%)$ under L-CS treatment affected the production of NO and TNF- $\alpha$ and enhanced the inhibitory effect of L-CS on adhesion regulation. Finally, sphingolipids (D-sphingosine and DL-dihydrosphingosine) did not strongly abrogate L-CSmediated $\mathrm{T}$ cell proliferation. Therefore our data suggest that de novo sphingolipid metabolism may represent an important aspect of immunomodulatory activities mediated by $\mathrm{T}$ cells and macrophages/monocytes, depending on serum level.

Acknowledgements This work was supported by a grant (2006-C00455) from KRF, Korea and author acknowledges 
to Miss Ji Yeon Lee for technical support.

\section{REFERENCES}

1) Elkins K. L., Cowley S. C., Bosio C. M., Ann. N.Y. Acad. Sci., 1105 284-324 (2007).

2) Brogdon J. L., Xu Y., Szabo S. J., An S., Buxton F., Cohen D., Huang Q., Blood, 109, 1123-1130 (2007).

3) Bryant P., Ploegh H., Curr. Opin. Immunol., 16, 96-102 (2004).

4) Lemos M. P., Fan L., Lo D., Laufer T. M., J. Immunol., 171, $5077-$ 5084 (2003).

5) Skapenko A., Leipe J., Lipsky P. E., Schulze-Koops H., Arthritis Res. Ther., 7 (Suppl. 2), S4-S14 (2005).

6) Corthay A., Adv. Exp. Med. Biol., 590, 195-208 (2007).

7) Alderman C. J., Bunyard P. R., Chain B. M., Foreman J. C., Leake D. S., Katz D. R., Cardiovasc. Res., 55, 806-819 (2002).

8) Cho J. Y., Chain B. M., Vives J., Horejsi V., Katz D. R., Exp. Cell Res., 290, 155-167 (2003).

9) Kaisho T., Akira S., J. Allergy Clin. Immunol., 117, 979-987; quiz 988 (2006).

10) Cho J. Y., Fox D. A., Horejsi V., Sagawa K., Skubitz K. M., Katz D. R., Chain B., Blood, 98, 374-382 (2001).

11) Colombaioni L., Garcia-Gil M., Brain Res. Brain Res. Rev., 46, 328 355 (2004).

12) Fukumoto S., Iwamoto T., Sakai E., Yuasa K., Fukumoto E., Yamada A., Hasegawa T., Nonaka K., Kato Y., J. Pharmacol. Sci., 100, 195200 (2006).

13) Rentz S. S., Showker J. L., Meredith F. I., Riley R. T., Food. Chem. Toxicol., 43, 123-131 (2005).

14) Linn S. C., Kim H. S., Keane E. M., Andras L. M., Wang E., Merrill A. H., Jr., Biochem. Soc. Trans., 29, 831-835 (2001).

15) Aki F. T., Kahan B. D., Expert Opin. Biol. Ther, 3, 665-681 (2003).

16) Yang Z., Chen M., Fialkow L. B., Ellett J. D., Wu R., Brinkmann V., Nadler J. L., Lynch K. R., Clin. Immunol., 107, 30-35 (2003).

17) Ueda H., Takahara S., Azuma H., Kusaka M., Suzuki S., Katsuoka Y., Eur. Surg. Res., 32, 279-283 (2000).

18) Holleran W. M., Williams M. L., Gao W. N., Elias P. M., J. Lipid Res., 31, 1655-1661 (1990).

19) Hanada K., Nishijima M., Fujita T., Kobayashi S., Biochem. Pharmacol., 59, 1211-1216 (2000).

20) Fenn T. D., Holyoak T., Stamper G. F., Ringe D., Biochemistry, 44, 5317-5327 (2005).

21) Mizrachi Y., Lev M., Harish Z., Sundaram S. K., Rubinstein A., J. Acquir. Immune Defic. Syndr. Hum. Retrovirol., 11, 137-141 (1996).

22) Tamma S. L., Sundaram S. K., Lev M., Coico R. F., Biochem. Biophys. Res. Commun., 220, 916-921 (1996).

23) Hanada K., Biochim. Biophys. Acta, 1632, 16-30 (2003).

24) Memon R. A., Holleran W. M., Uchida Y., Moser A. H., Grunfeld C., Feingold K. R., J. Lipid Res., 42, 452-459 (2001).

25) Cho J. Y., Skubitz K. M., Katz D. R., Chain B. M., Exp. Cell Res., 286, $1-11(2003)$

26) Zhu H., Yang J., Murphy T. L., Ouyang W., Wagner F., Saparov A., Weaver C. T., Murphy K. M., J. Immunol., 167, 855-865 (2001).

27) Cho J. Y., Baik K. U., Jung J. H., Park M. H., Eur. J. Pharmacol., 398, 399-407 (2000)

28) Zhou M., Ouyang W., Gong Q., Katz S. G., White J. M., Orkin S. H., Murphy K. M., J. Exp. Med., 194, 1461-1471 (2001).

29) Kim A. R., Cho J. Y., Lee J. Y., Choi J. S., Chung H. Y., J. Pharm Pharmacol., 57, 475-481 (2005).

30) Hong S., Kim S. H., Rhee M. H., Kim A. R., Jung J. H., Chun T., Yoo
E. S., Cho J. Y., Naunyn. Schmiedebergs Arch. Pharmacol., 368, $448-456$ (2003).

31) Lee H. J., Hyun E. A., Yoon W. J., Kim B. H., Rhee M. H., Kang H. K., Cho J. Y., Yoo E. S., J. Ethnopharmacol., 103, 208-216 (2006).

32) Colombaioni L., Frago L. M., Varela-Nieto I., Pesi R., Garcia-Gil M., Neurochem. Int., 40, 327-336 (2002).

33) Yu M. U., Yoo J. M., Lee Y. S., Lee Y. M., Hong J. T., Oh K. W., Song S., Yun Y. P., Yoo H. S., Oh S., J. Toxicol. Environ. Health A, 67, 2085-2094 (2004).

34) Albi E., Cataldi S., Bartoccini E., Magni M. V., Marini F., Mazzoni F., Rainaldi G., Evangelista M., Garcia-Gil M., J. Cell Physiol., 206, 189-195 (2006).

35) Miyake Y., Kozutsumi Y., Nakamura S., Fujita T., Kawasaki T., Biochem. Biophys. Res. Commun., 211, 396- 403 (1995).

36) Yanagawa Y., Hoshino Y., Kataoka H., Kawaguchi T., Ohtsuki M., Sugahara K., Chiba K., Transplant. Proc., 31, 1227-1229 (1999).

37) Bohler T., Waiser J., Schuetz M., Neumayer H. H., Budde K., Nephrol. Dial. Transplant., 19, 702-713 (2004).

38) O’Neill L. A., Trends Immunol., 23, 296-300 (2002).

39) Arai T., Bhunia A. K., Chatterjee S., Bulkley G. B., Circ. Res., 82, 540-547 (1998).

40) Iwamoto T., Fukumoto S., Kanaoka K., Sakai E., Shibata M., Fukumoto E., Inokuchi Ji. J., Takamiya K., Furukawa K., Furukawa K., Kato Y., Mizuno A., J. Biol. Chem., 276, 46031-46038 (2001).

41) Kester M., Kolesnick R., Pharmacol. Res., 47, 365-371 (2003).

42) Cuvillier O., Biochim. Biophys. Acta, 1585, 153-162 (2002).

43) Pannu R., Won J. S., Khan M., Singh A. K., Singh I., J. Neurosci., 24, 5942-5954 (2004).

44) Rizzieri K. E., Hannun Y. A., Drug Resist. Update, 1, 359-376 (1998).

45) Segui B., Andrieu-Abadie N., Jaffrezou J. P., Benoist H., Levade T., Biochim. Biophys. Acta, 1758, 2104-2120 (2006).

46) Yang J., Yu Y., Sun S., Duerksen-Hughes P. J., Cell. Biochem. Biophys., 40, 323-350 (2004).

47) Wang H., Giuliano A. E., Cabot M. C., Mol. Cancer Ther., 1, 719 726 (2002).

48) Nojiri H., Takaku F., Terui Y., Miura Y., Saito M., Proc. Natl. Acad. Sci. U.S.A., 83, 782-786 (1986).

49) Maupas-Schwalm F., Auge N., Robinet C., Cambus J. P., Parsons S. J., Salvayre R., Negre-Salvayre A., FASEB J., 18, 1398-1400 (2004).

50) Pasquier B., Yin L., Fondaneche M. C., Relouzat F., Bloch-Queyrat C., Lambert N., Fischer A., de Saint-Basile G., Latour S., J. Exp. Med., 201, 695-701 (2005).

51) Rodriguez-Lafrasse C., Alphonse G., Aloy M. T., Ardail D., Gerard J. P., Louisot P., Rousson R., Int. J. Cancer, 101, 589-598 (2002).

52) Manthey C. L., Schuchman E. H., Cytokine, 10, 654 -661 (1998).

53) Billich A., Bornancin F., Mechtcheriakova D., Natt F., Huesken D., Baumruker T., Cell Signal., 17, 1203-1217 (2005).

54) Hedlund M., Duan R. D., Nilsson A., Svanborg C., Mol. Microbiol., 29, 1297-1306 (1998).

55) Wu F., Grossenbacher D., Gehring H., Mol. Cancer Ther, 6, 18311839 (2007).

56) Matsubara K., Matsumoto H., Mizushina Y., Lee J. S., Kato N., Int. J. Mol. Med., 12, 51-55 (2003).

57) Mizushina Y., Xu X., Matsubara K., Murakami C., Kuriyama I., Oshige M., Takemura M., Kato N., Yoshida H., Sakaguchi K., Biochem. Biophys. Res. Commun., 312, 1025-1032 (2003).

58) Batheja A. D., Uhlinger D. J., Carton J. M., Ho G., D’Andrea M. R., J. Histochem. Cytochem., 51, 687-696 (2003). 